\title{
PENGGUNAAN MEDIA ANIMASI TULISAN TANGAN UNTUK MENINGKATKAN KETERAMPILAN MENULIS KARANGAN DESKRIPSI PADA MAHASISWA
}

\author{
Rini Sri Indriani ${ }^{\left.a^{*}\right)}$, Yuli Mulyawati ${ }^{a)}$, Mira Mirawati ${ }^{a)}$ \\ ${ }^{a)}$ Universitas Pakuan, Bogor, Indonesia \\ ${ }^{*}$ e-mail korespondensi : rini_sriindriani@ymail.com
}

Riwayat Artikel : diterima: 25 Januari 2020; direvisi: 29 Januari 2020; disetujui: 06 Februari 2020

\begin{abstract}
Abstrak. Salah satu fungsi mata kuliah Pembelajaran Bahasa dan Sastra Indonesia secara umum adalah sebagai sarana peningkatan pengetahuan dan keterampilan berbahasa Indonesia untuk meraih dan mengembangkan ilmu pengetahuan, teknologi, dan seni. Penelitian ini dilaksanakan pada tanggal 20 November 2019 di Kelas 5D PGSD FKIP UNPAK dengan jumlah 26 orang terdiri dari 3 orang laki-laki dan 23 orang perempuan,Tahun Akademik Gasal 2019-2020. Hasil penelitian yang peneliti lakukan diolah dengan menggunakan statistik deskriptif. Berdasarkan penelitian yang dilakukan tentang penilaian karangan deskriptif dengan menggunakan media Animasi Tulisan Tangan diperoleh hasil rekapitulasinya sebagai berikut : Untuk isi atau gagasan yang dikemukakan memperoleh nilai 77 dengan kriteria Sangat baik. Organisasi isi memperoleh nilai 78 dengan kriteria Sangat Baik. Tata Bahasa memperoleh nilai 78 dengan kriteria Sangat Baik. Gaya: pilihan struktur dan kosakata memperoleh nilai 76 dengan kriteria Sangat Baik. Hasil rekapitulasi Penilaian penggunaan media animasi Tulisan tangan pada pembuatan karangan deskriptif untuk indikator kesesuaian materi 100\% mahasiswa telah sesuai sehingga kriterianya Sangat Baik,. Durasi pembuatan animasi 100\% telah sesuai dengan waktu yang telah ditetapkan yaitu maksimal 30 menit sehingga kriterianya Sangat Baik. Keindahan penampilan dalam animasi Tulisan Tangan yang telah dibuat hanya $75 \%$ dengan kriteria Sangat Baik. Tulisan yang dibuat memperoleh $100 \%$ sesuai sehingga kriterianya Sangat Baik.
\end{abstract}

Kata Kunci: keterampilan menulis; karangan deskripsi; media animasi tulisan tangan

\section{USE OF HAND WRITING ANIMATION MEDIA TO IMPROVE WRITING SKILLS DESCRIPTION OF DESCRIPTION IN STUDENTS}

Abstract. One of the functions of the Indonesian Language and Literature Learning course in general is as a means of increasing knowledge and skills in Indonesian language to gain and develop science, technology, and art. This research was conducted on November 20, 2019 in Class 5D PGSD FKIP UNPAK with a total of 26 people consisting of 3 men and 23 women, Odd Academic Year 2019-2020. The results of research that researchers do are processed using descriptive statistics. Based on research conducted on the assessment of descriptive essays using Handwriting Animation media, the recapitulation results are obtained as follows: For the content or ideas expressed, obtained a score of 77 with very good criteria. Content organizations score 78 with Very Good criteria. Grammar scores 78 with Very Good criteria. Style: choice of structure and vocabulary scored 76 with Very Good criteria. Results of recapitulation Assessment of the use of animated media Handwriting on the making of descriptive essays for indicators of the suitability of the material $100 \%$ of students are in conformity so that the criteria are Very Good ,. The duration of making animation $100 \%$ in accordance with the time that has been set is a maximum of 30 minutes so the criteria are Very Good. The beauty of the appearance in Handwritten animation that has been made is only $75 \%$ with the criteria Very Good. Posts that are made get $100 \%$ accordingly so that the criteria are very good..

Keywords: writing skills; essay description; handwritten animation media

\section{PENDAHULUAN}

Pembelajaran Bahasa Indonesia diarahkan guna meningkatkan kemampuan peserta didik untuk berkomunikasi dalam Bahasa Indonesia dengan baik dan benar, baik secara lisan maupun tulisan, serta menumbuhkan apresiasi terhadap hasil karya kesastraan manusia Indonesia [1]. Mata Kuliah Pembelajaran Bahasa dan Sastra Indonesia adalah mata kuliah yang mempelajari keterampilan berbahasa yang terdiri dari empat aspek, yaitu menyimak atau mendengarkan, berbicara, membaca, dan menulis. Mahasiswa harus menguasai keempat aspek tersebut agar terampil berbahasa. Salah satu faktor yang sangat berpengaruh pada hasil pendididikan adalah kegiatan pembelajaran [2]. Pembelajaran pada dasarnya merupakan proses interaksi antara guru dan siswa. Dalam setiap proses pembelajaran yang berlangsung terdapat tujuan pembelajaran yang harus dicapai. Untuk mencapai tujuan yang diharapkan, ada hal yang yang perlu diperhatikan dalam menunjang proses belajar mengajar seperti model, metode, ataupun media pembelajaran yang sesuai dengan materi yang akan disampaikan. Pada kenyataannya masih ada beberapa masalah, seperti media, fasilitas, dan penerapannya yang kurang efektif. Ada beberapa faktor yang dapat membuat proses pembelajaran berlangsung lebih efektif, salah satunya adalah media pembelajaran. Menurut pendapat Daryanto [3] sumber belajar adalah segala sesuatu 
yang ada di sekitar lingkungan kegiatan belajar yang secara fungsional dapat digunakan untuk membantu optimalisasi hasil belajar dari segi proses dan hasil belajar. Penggunaan media pembelajaran yang tepat akan membantu guru menyampaikan pembelajaran atau memberikan penguatan terhadap materi yang disampaikan.

Gagne (Sadiman [4]) menyatakan bahwa media adalah berbagai jenis komponen dalam lingkungan siswa yang dapat merangsangnya untuk belajar. Sementara itu Briggs (Sadiman [4]) berpendapat bahwa media adalah segala alat fisik yang dapat menyajikan pesan serta merangsang siswa untuk belajar, contohnya buku, film, kaset, dan film bingkai. Berkenaan dengan pembelajaran menulis karangan deskripsi, berdasarkan hasil observasi penelitian mahasiswa PGSD semester V menyatakan mahasiswa mengalami hambatan ketika menulis karangan deskripsi, yakni dikarenakan (1) mahasiswa belum mampu mengembangkan tema karangan, (2) mahasiswa kesulitan dalam menentukan pilihan kata dan kurangnya kosakata yang dimiliki, (3) mahasiswa kesulitan merangkai kata-kata dalam kesatuan makna karangan, serta (4) rendahnya minat untuk menulis karangan deskripsi. Untuk mempermudah dalam menulis karangan deskripsi, perlu diperhatikan beberapa langkah dalam menulis karangan deskripsi. Mohamad Yunus dan Suparno [5] mengemukakan bahwa untuk mempermudah pendeskripsian, perlu diperhatikan langkah-langkah sebagai berikut. a) Menentukan apa yang akan dideskripsikan: Apakah akan mendeskripsikan orang atau tempat. b) Merumuskan tujuan pendeskripsian: Apakah deskripsi dilakukan sebagai alat bantu karangan narasi, eksposisi, argumentasi, atau persuasi. c) Menetapkan bagian yang akan dideskripsikan: kalau yang dideskripsikan orang, apakah yang akan dideskripsikan itu ciri-ciri fisik, watak, gagasannya, atau benda-benda disekitar tokoh? Kalau yang dideskripsikan tempat, apakah yang dideskripsikan keseluruhan tempat atau hanya bagian-bagian tertentu saja yang menarik? d) Merinci dan menyistematiskan hal-hal yang menunjang kekuatan bagian yang akan dideskripsikan. Hamalik dalam Azhar Arsyad [6] mengemukakan bahwa pemakaian media pembelajaran dalam proses pembelajaran dapat membangkitkan keinginan dan minat yang baru, membangkitkan motivasi dan rangsangan kegiatan belajar, dan membawa pengaruh-pengaruh psikologis terhadap siswa.

Diharapkan dengan adanya penelitian ini dapat memecahkan masalah yang terjadi di antaranya solusi untuk meningkatan keterampilan menulis karangan deskripsi mahasiswa semester V. Salah satu solusi untuk permasalahan menulis karangan deskripsi mahasiswa yaitu dengan menggunakan media pembelajaran yang tepat, hal itu untuk meningkatkan keterampilan menulis karangan deskripsi mahasiswa. Media pembelajaran yang digunakan selain harus tepat dan sesuai, juga harus menarik, agar mahasiswa termotivasi untuk menulis karangan deskripsi.

Media pembelajaran animasi akan membantu dan memudahkan dalam menulis sebuah karangan. Menurut Salim [7], animasi adalah proses penciptaan efek gerak atau efek perubahan bentuk yang terjadi selama beberapa waktu (morphing). Salah satu keunggulan animasi adalah kemampuannya untuk menjelaskan suatu kejadian secara sistematis dalam tiap waktu perubahan. Media animasi ini adalah untuk membuat hasil pembuktian mahasiswa dengan membuat VideoScribe. Animasi tangan ini dapat seirama dengan objek berupa teks atau gambar yang ditampilkan pada layar, sehingga bila dilihat seperti tangan sipembuat sendiri yang melakukannya. Keunikan dari videoscribe terletak pada penjelasan suatu topik dengan media gambar dan tulisan yang ditulis atau digambar. Untuk memperjelas permasalahan yang akan diteliti, maka masalah tersebut harus dirumuskan terlebih dahulu. Adapun rumusan masalah dalam penelitian ini adalah sebagai berikut. (1) Bagaimana proses pembelajaran menulis karangan deskripsi dengan menggunakan media animasi tulisan tangan pada mahasiswa semester V? (2) Bagaimana peningkatan kemampuan menulis karangan deskripsi mahasiswa semester $\mathrm{V}$ dengan menggunakan media animasi tulisan tangan?

\section{METODE PENELITIAN}

Adapun jenis pendekatan penelitian ini adalah deskriptif. Penelitian deskriptif yaitu penelitian yang berusaha untuk menuturkan pemecahan masalah yang ada sekarang berdasarkan data-data.Jenis penelitian deskriptif kualitatif yang digunakan pada penelitian ini. Penelitian dilaksanakan di Prodi PGSD Fakultas Keguruan dan Ilmu Pendidikan Unversitas Pakuan Bogor. Subjek penelitian ini adalah Mahasiswa PGSD Semester V semester Gasal tahun akademik 2019/2020.

Sesuai dengan karakteristik data yang diperlukan dalam penelitian ini, maka teknik pengumpulan data yang dilakukan adalah Observasi, Dokumentasi, Instrumen Penelitian [8], dengan cara mengorganisasikan data ke dalam kategori, menjabarkan ke dalam unit-unit, melakukan sintesa, menyusun ke dalam pola, memilih mana yang penting dan yang akan di pelajari, dan membuat kesimpulan sehingga mudah dipahami oleh diri sendiri dan orang lain. Analisis data dalam penelitian kualitatif dilakukan sejak sebelum memasuki lapangan, selama di lapangan dan setelah selesai di lapangan. Penelitian kualitatif harus mengungkap kebenaran yang objektif. Karena itu keabsahan data dalam sebuah penelitian kualitatif sangat penting. Melalui keabsahan data kredibilitas (kepercayaan) penelitian kualitatif dapat tercapai. Keabsahan data diperlukan teknik pemeriksaan yang didasarakan pada sejumlah kriteria tertentu. Ada empat kriteria yang digunakan, yaitu kredibilitas (derajat kepercayaan), keteralihan (tranferbility), kebergantungan (dependenbility), kepastian (conformability). Lexy J. Moleong [9]

\section{HASIL DAN PEMBAHASAN}

Mata kuliah Pembelajaran Bahasa dan Sastra Indonesia merupakan Mata Kuliah yang menuntut mahasiswa untuk dapat memiliki kemampuan berbahasa baik secara lisan maupun tulisan. Dalam kebahasaan 
mahasiswa dituntut untuk memiliki kemampuan berbahasa yang sesuai dengan Ejaan yang di sempurnakan.

Penelitian ini dilaksanakan pada tanggal 20 November 2019 di Kelas 5D PGSD FKIP UNPAK dengan jumlah 3 orang laki-laki dan 23 orang perempuan Tahun Akademik Gasal 2019-2020.Hasil penelitian yang peneliti lakukan diolah dengan menggunakan statistik deskriptif. Deskripsi data hasil penelitian dikelompokkan menjadi dua bagian, yang terdiri dari:

1. Penilaian Konten Karangan Deskripsi dengan Menggunakan Animasi Tulisan Tangan

a. Penilaian isi atau gagasan yang dikemukakan

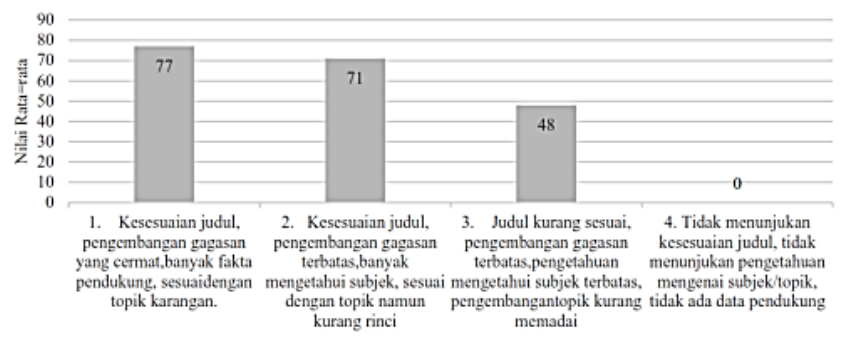

Gambar 1. Penilaian isi atau gagasan yang dikemukakan

Berdasarkan Gambar 1 Penilaian isi atau gagasan yang dikemukaan dengan indikator kesesuaian judul, pengembangan gagasan yang cermat, banyak fakta pendukung sesuai dengan topik karangan. Dari 26 mahasiswa yang membuat karangan hanya 23 mahasiswa yang sesuai karangannya sehingga memperoleh nilai ratarata 77 dengan kriteria Sangat baik. Untuk indikator kesesuaian judul, pengembangan gagasan terbatas, banyak mengetahui subjek, sesuai dengan topik namun kurang rinci hanya 21 mahasiswa sesuai karangannya sehingga memperoleh nilai rata-rata 71 dengan kriteria Baik. Untuk indikator Judul kurang sesuai, pengembangan gagasan terbatas, pengetahuan mengetahui subjek terbatas, pengembangan topik kurang memadai hanya 11 mahasiswa yang kurang sesuai sehingga memperoleh nilai rata-rata 48 dengan kriteria Cukup Baik. Sedangkan untuk indikator Tidak menunjukkan kesesuaian judul, tidak menunjukkan pengetahuan mengenai subjek/topik, tidak ada data pendukung tidak ada seorang pun menunjukkan hal tersebut sehingga nilainya 0

\section{b. Penilaian Organisasi Isi Karangan}

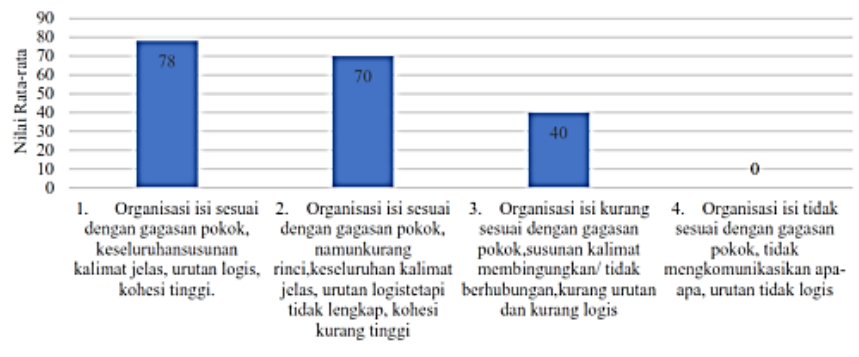

Gambar 2. Aspek Penilaian Organisasi Isi Karangan
Berdasarkan gambar 2 Penilaian Organisasi isi karangan dengan indikator Organisasi isi sesuai dengan gagasan pokok, keseluruhan susunan kalimat jelas, urutan logis, kohesi tinggi terdapat 24 mahasiswa yang sesuai memperoleh nilai rata-rata 78 dengan kriteria Sangat Baik. Untuk indikator Organisasi isi sesuai dengan gagasan pokok, namun kurang rinci, keseluruhan kalimat jelas, urutan logis tetapi tidak lengkap, kohesi kurang tinggi ada 20 mahasiswa yang kurang rinci dan kurang kohesi dalam pembuatan karangan memperoleh nilai rata-rata 70 dengan kriteria Baik. Untuk indikator Organisasi isi kurang sesuai dengan gagasan pokok, susunan kalimat membingungkan/ tidak berhubungan, kurang urutan dan kurang logis ada 10 mahasiswa yang kurang sesuai oranisasi isi karangannya memperoleh nilai rata-rata 40 dengan kriteria Baik. Untuk Indikator Organisasi isi tidak sesuai dengan gagasan pokok, tidak mengkomunikasikan apa-apa, urutan tidak logis tidak ada seorang pun mahasiswa yang melakukan kesalahan ini sehingga nilainya 0 .

\section{c. Penilaian Tata Bahasa dalam Karangan}

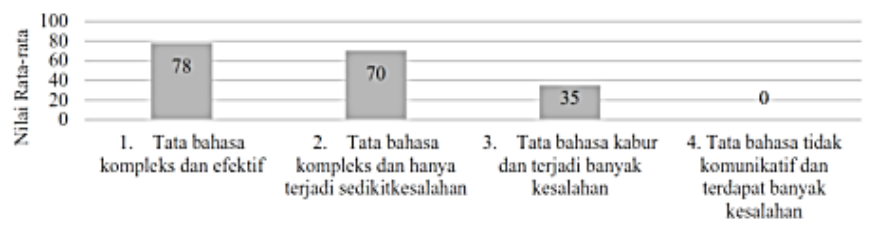

Gambar 3. Aspek penilaian tata bahasa

Berdasarkan Gambar 3 Penilaian Tata Bahasa dalam Karangan dengan indikator tata bahasa kompleks dan efektif ada 24 mahasiswa yang tata bahasanya kompleks dan efektif dengan memperoleh nilai rata-rata 78 kriterianya Sangat Baik. Untuk indikator Tata bahasa kompleks dan hanya terjadi sedikit kesalahan, ada 20 mahasiswa yang hanya terjadi sedikit kesalahan dengan memperoleh nilai rata-rata 70 kriterianya Baik. Untuk indikator Tata bahasa kabur dan terjadi banyak kesalahan ada 9 mahasiswa yang tata bahasanya kabur dengan memperoleh nilai rata-rata 35 kriterinya Cukup Baik. Sedangkan untuk indikator Tata bahasa tidak komunikatif dan terdapat banyak kesalahan tidak seorang pun mahasiswa melakukannya sehingga nilainya 0 .

\section{d. Penilaian Gaya : Pilihan struktur dan kosakata}

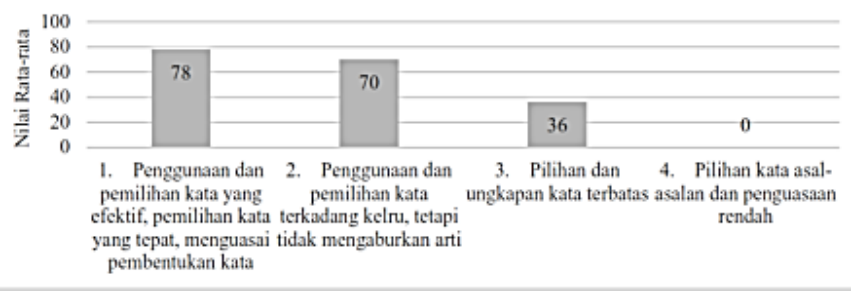

Gambar 4. Aspek Penilaian Gaya : Pilihan struktur dan kosakata 
Berdasarkan Gambar 4 penilaian gaya : pilihan struktur dan kosakata dengan indikator Penggunaan dan pemilihan kata yang efektif, pemilihan kata yang tepat, menguasai pembentukan kata ada 24 mahasiswa yang dapat menggunakan pemilihan kata yang efektif dengan nilai ratarata 78 kriterianya Sangat Baik. Untuk indikator Penggunaan dan pemilihan kata terkadang keliru, tetapi tidak mengaburkan arti ada 20 mahasiswa yang penggunaanya masih keliru tapi tidak mengaburkan arti dengan nilai ratarata 70 kriterianya sangat baik. Untuk Indikator Pilihan dan ungkapan kata terbatas hanya ada 9 mahasiswa yang ungkapan kata terbatas dengan nilai rata-rata 36 kriterianya Cukup Baik. Untuk indikator Pilihan kata asal-asalan dan penguasaan rendah tidak ada seorang pun mahasiswa yang pilihan katanya asal-asalan sehingga nilainya 0

\section{e. Penilaian Ejaan dan Tata Tulis}

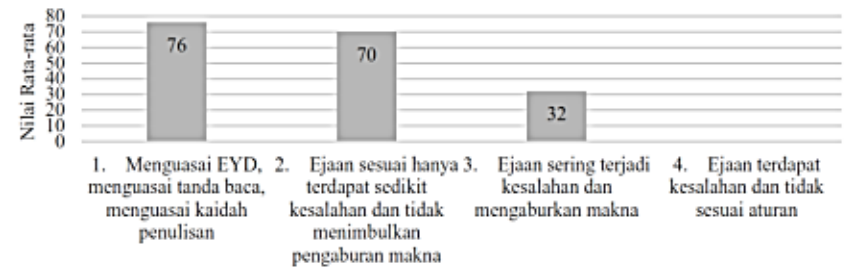

Gambar 5. Aspek Penilaian Ejaan dan Tata Tulis

Berdasarkan Gambar 5 Penilaian Ejaan dan Tata Tulis dengan indikator Menguasai EYD, menguasai tanda baca, menguasai kaidah penulisan ada 23 mahasiswa yang menguasai EYD dengan nilai rata-rata 76 kriterianya Sangat Baik. Untuk Indikator Ejaan sesuai hanya terdapat sedikit kesalahan dan tidak menimbulkan pengaburan makna ada 20 Mahasiswa yang melakukan sedikit kesalahan dengan nilai rata-rata 70 kriterianya Baik. Untuk indikator Ejaan sering terjadi kesalahan dan mengaburkan makna ada 7 Mahasiswa yang melakukan kesalahan dan mengaburkan makna dengan nilai rata-rata 32 kriterianya Cukup Baik. Untuk indikator Ejaan terdapat kesalahan dan tidak sesuai aturan tidak ada seorang pun mahasiswa yang melakukan kesalahan sehingga nilainya 0 .

\section{Penilaian Pembuatan Animasi Tulisan Tangan}

Tabel 1. Penilaian Tulisan Tangan Animasi

\begin{tabular}{|c|l|c|c|c|}
\hline No. & \multicolumn{1}{|c|}{ Aspek } & Nilai & Prosentase & Kriteria \\
\hline 1 & Kesesuaian materi & 30 & 100 & Sangat Baik \\
\hline 2 & Durasi & 20 & 100 & Sangat Baik \\
\hline 3 & Keindahan tampilan & 15 & 75 & Sangat Baik \\
\hline 4 & Tulisan Menarik & 30 & 100 & Sangat Baik \\
\hline \multicolumn{2}{|c|}{ Jumlah } & 95 & 95 & Sangat Baik \\
\hline
\end{tabular}

Berdasarkan Tabel 1. Penilaian Tulisan Tangan Animasi Tulisan Tangan dari 26 mahasiswa untuk indikator kesesuaian materi nilai rata-ratanya 30 yang berarti bahwa $100 \%$ animasi yang mahasiswa buat sudah sesuai dengan kriteria Sangat Baik. Untuk indikator durasi nilai rata-rata 20 yang berarti bahwa $100 \%$ animasi yang dibuat mahasiswa durasinya sudah sesuai dengan kriteria Sangat Baik. Untuk indikator keindahan tampilan nilai rata-ratanya 15 yang berarti bahwa hanya $75 \%$ animasi yang dibuat mahasiswa indah tampilannya dengan kriterianya Sangat Baik. Untuk Indikator tulisan menarik nilai rata-ratanya 20 yang berarti bahwa $100 \%$ animasi yang dibuat mahasiswa tulisannya menarik dengan kriteria Sangat Baik.

Penulisan karangan deskripsi merupakan karangan yang lebih menggabarkan situasi atau keadaan dalam sebuah karangan, untuk itu karangan deskrptif haruslah dapat lebih memfokuskan kepada hal yang sifatnya lebih real atau nyata. Dalam pembuatan sebuah karangan deskriptif tentu saja ada aturan-aturan yang harus diketahui oleh pembuat karangan antara lain tentang isi atau gagasan yang dikemukakan harus sesuai, organisasi isi karangan juga harus sesuai serta pemilihan struktur kosakata harus diperhatikan. Hal inilah yang menjadi tolok ukur dalam pembuatan karangan deskriptif. Kata deskripsi berasal dari kata bahasa Latin describere yang berarti menggambarkan atau memerikan suatu hal. Dari segi istilah, karangan deskripsi adalah karangan yang tujuannya untuk memberikan rincian atau detail tentang objek sehingga dapat memberi pengaruh pada emosi dan menciptakan imajinasi pembaca bagaikan melihat, mendengar, atau merasakan langsung apa yang disampaikan penulis (Semi, [10]). Jadi dapat disimpulkan bahwa karangan deskripsi merupakan salah satu ragam karangan yang menggambarkan suatu objek. Karangan deskripsi memiliki karakteristik yang berbeda dengan karangan lain. Objek tersebut dapat berupa objek orang maupun tempat. Dalam menulis karangan deskripsi perlu memperhatikan langkah-langkah penulisan untuk mempermudah pendeskripsian. Proses penulisan karangan deskripsi meliputi tahap perencanaan, tahap penulisan, dan tahap revisi [11].

Penelitian yang dilakukan tentang penilaian karangan deskriptif dengan menggunakan media Animasi Tulisan Tangan diperoleh hasil rekapitulasinya sebagai berikut : Untuk isi atau gagasan yang dikemukakan memperoleh nilai 77 dengan kriteria Sangat baik. Organisasi isi memperoleh nilai 78 dengan kriteria Sangat Baik. Tata Bahasa memperoleh nilai 78 dengan kriteria Sangat Baik. Gaya: pilihan struktur dan kosakata memperoleh nilai 76 dengan kriteria Sangat Baik.

Berdasarkan hal tersebut bahwa keterampilan menulis karangan deskriptif mahasiswa meskipun telah masuk kriteria sangat baik akan tetapi nilainya masih belum memperoleh nilai yang maksimal, untuk itu peningkatan penggunaan media pembelajaran perlu dilakukan untuk meningkatkan hasil belajar mahasiswa.

Penelitian yang dilakukan bahwa peneliti menggunakan media animasi Tulisan Tangan karena di era digital seperti sekarang penggunaan teknologi dalam pembelajaran sangat diperlukan, hal ini agar mahasiswa tidak bosan serta mahasiswa dapat melek akan teknologi dalam pembelajaran. Animasi Tulisan Tangan adalah aplikasi yang dibuat untuk memudahkan mahasiswa supaya dapat membuat berbagai jenis tampilan yang menarik dengan menggunakan ikon-ikon sehingga tampilan yang 
muncul lebih menarik. Suheri [12] juga mengatakan bahwa animasi memiliki kemampuan untuk memaparkan sesuatu yang rumit atau kompleks atau sulit untuk dijelaskan dengan gambar atau kata-kata saja.

Media animasi ini adalah untuk membuat hasil pembuktian mahasiswa dengan membuat VideoScribe. Animasi tangan ini dapat seirama dengan objek berupa teks atau gambar yang ditampilkan pada layar, sehingga bila dilihat seperti tangan sipembuat sendiri yang melakukannya. Keunikan dari videoscribe terletak pada penjelasan suatu topik dengan media gambar dan tulisan yang ditulis atau digambar. Media Animasi Tulisan Tangan dapat dibuat dalam visual yang diproyeksikan atau dapat pula dibuat dalam bentuk audio visual yang diproyeksikan.

Penelitian yang dilakukan menggunakan animasi Tulisan Tangan ini dalam bentuk audio visual sehingga lebih menarik. Hasil rekapitulasi Penilaian penggunaan media animasi Tulisan tangan pada pembuatan karangan deskriptif untuk indikator kesesuaian materi $100 \%$ mahasiswa telah sesuai sehingga kriterianya Sangat Baik,. Durasi pembuatan animasi $100 \%$ telah sesuai dengan waktu yang telah ditetapkan yaitu maksimal 30 menit sehingga kriterianya Sangat Baik. Keindahan penampilan dalam animasi Tulisan Tangan yang telah dibuat hanya $75 \%$ dengan kriteria Sangat Baik. Tulisan yang dibuat memperoleh $100 \%$ sesuai sehingga kriterianya Sangat Baik:

\section{SIMPULAN}

Berdasarkan penelitian yang dilakukan tentang penilaian karangan deskriptif dengan menggunakan media Animasi Tulisan Tangan diperoleh hasil rekapitulasinya sebagai berikut : Untuk isi atau gagasan yang dikemukakan memperoleh nilai 77 dengan kriteria Sangat baik. Organisasi isi memperoleh nilai 78 dengan kriteria Sangat Baik. Tata Bahasa memperoleh nilai 78 dengan kriteria Sangat Baik. Gaya: pilihan struktur dan kosakata memperoleh nilai 76 dengan kriteria Sangat Baik.

Hasil rekapitulasi Penilaian penggunaan media animasi Tulisan tangan pada pembuatan karangan deskriptif untuk indikator kesesuaian materi $100 \%$ mahasiswa telah sesuai sehingga kriterianya Sangat Baik,. Durasi pembuatan animasi $100 \%$ telah sesuai dengan waktu yang telah ditetapkan yaitu maksimal 30 menit sehingga kriterianya Sangat Baik. Keindahan penampilan dalam animasi Tulisan Tangan yang telah dibuat hanya $75 \%$ dengan kriteria Sangat Baik. Tulisan yang dibuat memperoleh $100 \%$ sesuai sehingga kriterianya Sangat Baik.

\section{REFERENSI}

[1] Saddhono, Kundharu. 2014. Pembelajaran Keterampilan Berbahasa Indoneisa Teori dan Aplikasi. Yogyakarta: Graha Ilmu.

[2] Kristiantari, Rini. 2004. Pembelajaran Menulis di Sekolah Dasar Menulis Deskripsi dan Narasi. Sidoarjo: Media Ilmu.
[3] Daryanto. 2016. Media Pembelajaran. Yogyakarta Gavamedia.

[4] Sadiman, A. 2009.Media Pendidikan (Pengertian, Pengembangan, dan Pemanfaatannya). Jakarta: PT Raja Grafindo Persada

[5] Suparno dan Mohamad Yunus. 2007. Keterampilan Dasar Menulis. Jakarta: Universitas Terbuka.

[6] Arsyad, A., 2011. Media Pembelajaran. Jakarta: Rajawali Pers.

[7] Salim, A. 2003. Animasi dengan Flash. Universitas Lampung.

[8] Sugiyono. 2012. Metode Penelitian Pendidikan (Pendekatan Kuantitatif, Kuali-tatif, dan R\&D). Bandung: Alfabet

[9] Moleong, Lexy J. 2009. Metode Penelitian Kualitatif. Bandung: RemajaRosdakarya

[10] Semi, M. Atar. 2007. Dasar-Dasar Keterampilan Menulis. Rev.ed. Bandung: Penerbit Angkasa

[11] Tarigan, Henry Guntur. 2008. Menulis sebagai Suatu Keterampilan Berbahasa. Bandung: Angkasa.

[12] Suheri Agus. 2006. Animasi Multimedia Pembelajaran. Jakarta : Elecmedia Komputindo. 